\title{
The impact of cattle dung pats on earthworm distribution in grazed pastures
}

\author{
M. G. Bacher ${ }^{1,2^{*}}$, O. Fenton ${ }^{1}$, G. Bondi ${ }^{1}$, R. E. Creamer ${ }^{3}$, M. Karmarkar $^{1}$ and O. Schmidt2,4
}

\begin{abstract}
Background: Grazed grassland management regimes can have various effects on soil fauna. For example, effects on earthworms can be negative through compaction induced by grazing animals, or positive mediated by increases in sward productivity and cattle dung pats providing a food source. Knowledge gaps exist in relation to the behaviour of different earthworm species i.e. their movement towards and aggregation under dung pats, the legacy effects of pats and the spatial area of recruitment. The present study addressed these knowledge gaps in field experiments, over 2 years, using natural and simulated dung pats on two permanent, intensively grazed pastures in Ireland.

Results: Dung pats strongly affected spatial earthworm distribution, with up to four times more earthworms aggregating beneath pats, than in the control locations away from pats. In these earthworm communities comprising 11 species, temporally different aggregation and dispersal patterns were observed, including absence of individual species from control locations, but no clear successional responses. Epigeic species in general, but also certain species of the anecic and endogeic groups were aggregating under dung. Sampling after complete dung pat disappearance (27 weeks after application) suggested an absence of a dung pat legacy effect on earthworm communities. Based on species distributions, the maximum size of the recruitment area from which earthworms moved to pats was estimated to be $3.8 \mathrm{~m}^{2}$ per dung pat. Since actual grazing over 6 weeks would result in the deposition of about 300 dung pats per ha, it is estimated that a surface area of $1140 \mathrm{~m}^{2}$ or about $11 \%$ of the total grazing area can be influenced by dung pats in a given grazing period.

Conclusions: This study showed that the presence of dung pats in pastures creates temporary hot spots in spatial earthworm species distribution, which changes over time. The findings highlight the importance of considering dung pats, temporally and spatially, when sampling earthworms in grazed pastures. Published comparisons of grazed and cut grasslands probably reached incorrect conclusions by ignoring or deliberately avoiding dung pats. Furthermore, the observed intense aggregation of earthworms beneath dung pats suggests that earthworm functions need to be assessed separately at these hot spots.
\end{abstract}

Keywords: Grassland, Earthworms, Lumbricidae, Soil fauna, Soil biodiversity, Sampling, Spatial distribution, Population aggregation, Populations

\section{Background}

Excluding Antarctica and Greenland, grasslands cover about $40 \%$ of the planet's terrestrial land area [1] and $\sim 26 \%$ of this area was grazed in 2005 [2]. In many parts of the world pasture based animal agriculture aims to increase both outputs and efficiency through intensification $[3,4]$. Such management regimes can have various

\footnotetext{
*Correspondence: matthiasbacher@web.de

${ }^{1}$ Teagasc, Environment Research Centre, Wexford, Ireland

Full list of author information is available at the end of the article
}

effects on soil fauna [5-7]. For example, intensification of grazing can have both negative and positive implications for earthworm abundance [8-10]. That is because compaction induced by grazing animals and/or machinery has been shown to limit earthworm activity by interfering with their mobility, feeding and reproduction [11], whereas associated increases in sward productivity and dung pats (or "-patches") left by grazing cattle provide a food source [12, 13]. Besides domestic grazers on managed pastures, a large variety of wild mammalian grazers and omnivores such as wild boar (Sus scrofa L.) spread 
their dung on natural grasslands [14-16]. Their droppings are equally important for dung fauna, including earthworms, and associated ecological processes such as bioturbation, nutrient cycling and decomposition of organic matter in these natural ecosystems are probably similar to those found in managed ecosystems.

The present work focused on the effects of cattle dung pat deposition on earthworm abundance and distribution within temperate, intensively grazed grassland. Considering the extent of grazed pasture systems, few studies have investigated dung-earthworm interactions and how earthworms aggregate under dung pats. For example, Holter [17] assessed the role of earthworms in dung disappearance in Denmark, while Hendriksen [18] studied dung feeding by detritivorous and geophagous earthworm species. Knight [19] and Svendsen et al. [20] found that earthworm numbers increased up to ten times under dung pats when compared with non-dung pat areas in English pastures. Similarly, James [16] quantified the aggregation of earthworms under bison dung pats in the Tallgrass prairie in Kansas, USA.

Even though all of these studies showed marked differences in earthworm abundance under dung and dung-free areas in grasslands, there is no evidence in the literature that this knowledge has been incorporated into earthworm sampling protocols [8, 13, 21-24] or taken into account in comparative studies of grazed and ungrazed grassland [6, 7]. Spatial earthworm distributions at large scales have been investigated with geo-statistical approaches [12, 25, 26]. At field scale, geostatistics has also been used to describe spatio-temporal earthworm distributions in forest [27] and savannah systems [28]. However, ephemeral resources such as dung pats that are known to affect the distribution of earthworm species have, apparently, not been taken into account. The lack of consideration of dung pats in earthworm sampling schemes is not really a knowledge gap but rather a failure to recognise and implement in protocols a phenomenon that has been documented in a scattered literature. Therefore, the main objective of the present research was to quantify the effect of dung pats on earthworm distributions and to highlight the need for recognition of dung-related patchiness of earthworm distributions when estimating earthworm population sizes and composition in grazed grasslands.

Other knowledge gaps still exist in relation to dung pats and earthworm ecology, including the temporal succession of different earthworm species, reflecting their attraction to dung and their mobility; the legacy effect of dung after decomposition on earthworms; and the effect of dung pats on the spatial dynamic of earthworm populations and their associated functions in soils immediately beneath pats and away from these 'hot spots'.
The hypotheses of the present study were:

1. Spatial earthworm distribution in grazed grassland is influenced by the aggregation under dung pats of different earthworm species, belonging to different ecological groups.

2. Temporal earthworm arrival at dung pats varies with species, e.g. in a successional manner and re-dispersal as dung pats degrade also varies with species.

3. Soil beneath dung pats keeps supporting larger earthworm populations even after full degradation occurred (legacy effect).

The present study tested these hypotheses using natural and simulated dung pats on two permanent, intensively grazed pasture sites in the SE of Ireland. Results were used to examine and discuss the practical implications in terms of (a) the spatial area of recruitment where earthworms migrate from towards dung pats, and (b) improved earthworm sampling techniques that consider dung pats.

\section{Results}

\section{Overall earthworm abundance and biomass}

Total-(sum of juvenile and adult earthworms) and juvenile earthworm abundance (Fig. 1) were significantly higher under the dung pat (DP) treatment than under the no-dung pat (NDP) treatment in both experiments (Experiment $1 \chi_{1}^{2}=46.9$, Experiment $2 \chi_{2}^{2}=110.5$, $\mathrm{p}<0.001$ with $1 \mathrm{DF}$ and $\mathrm{n}=50$ ). The earthworm abundance peak in DP treatment reached an average of $173 \pm 37$ individuals per sampling area $\left(0.09 \mathrm{~m}^{2}\right)$ in Experiment 1, which translated into a population equivalent of 1900 individuals $\mathrm{m}^{-2}$, and $360 \pm 60$ (Experiment 2) equivalent to $4000 \mathrm{~m}^{-2}$. The earthworm biomass (dead weight including gut content) peak reached an average of $40 \pm 10 \mathrm{~g}$ per sampling area, which translated into a population equivalent of $444 \mathrm{~g} \mathrm{~m}^{-2}$ (Experiment 1) and $106 \mathrm{~g} \pm 20$ per sampling area (Experiment 2) equivalent to $1182 \mathrm{~g} \mathrm{~m}^{-2}$.

Considering temporal trends of the overall earthworm abundance, the first sampling after 2 weeks already showed significantly higher abundances under the DP treatment; however, peak abundance, biomass and juvenile abundance under the DP treatment was reached after 7 (Experiment 2; Fig. 1) to 8 weeks (Experiment 1; Fig. 1).

\section{Experiment specific earthworm abundance}

Earthworm abundance under the DP treatment was generally much higher in Experiment 2 than in Experiment 1, while the NDP treatment abundances were similar in the two experiments (Fig. 1). Earthworm abundance under 


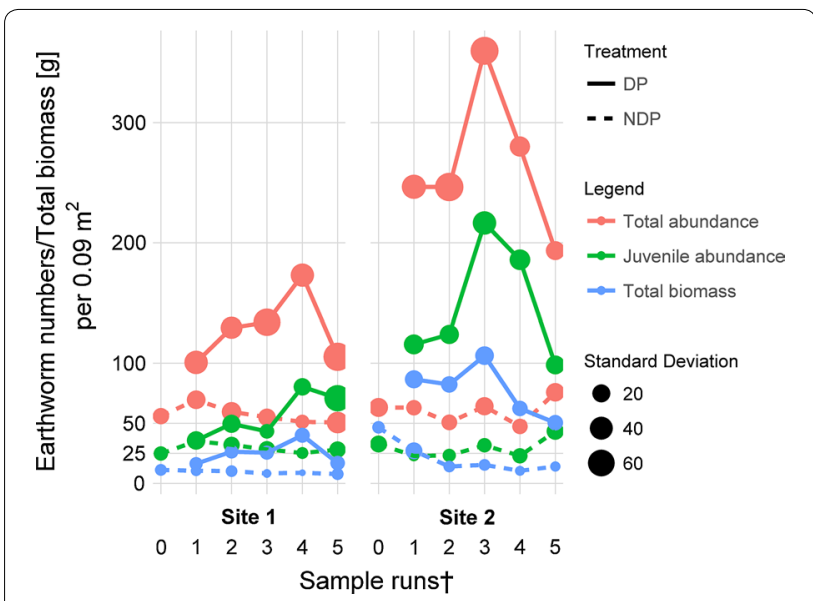

Fig. 1 Average earthworm abundance (total and juveniles), as well as total earthworm dead biomass (g) recorded under dung pats (DP) and non-dung pat treatment (NDP). The size of the points indicates the standard deviation per sampling run. ${ }^{\dagger}$ For sampling dates and intervals, please see Table 2

the DP treatment in Experiment 1 ranged (inter quartile range, IQR) from 95 to 164 individuals per sample and in Experiment 2 from 210 to 420 individuals. Control earthworm abundance in both experiments ranged (IQR) from 30 to 80 without significant differences ( $t$ test $t_{24}=0.56$, $\mathrm{p}$-value $=0.58)$. Following this trend, earthworm biomass and juvenile abundance under the DP treatment in Experiment 2 were three to five times higher than in Experiment 1, while NDP treatment biomass and juvenile abundance during dung presence were only slightly larger in Experiment 2. From a temporal perspective earthworm biomass and juvenile abundance under dung showed a slower rate of increase in Experiment 1 than in Experiment 2 (Fig. 1).

\section{Temporal and species effects}

Twelve earthworm species were found in total, of which one species was exclusive to each site. The effect of the DP treatment on different species varied in intensity and over time. All ecological groups included species attracted to the DP treatment during one or all sampling runs (except legacy run). Anecic species were generally attracted but low abundances of adults led to less robust results. Endogeic species showed mixed behaviour, with two species showing predominantly attraction and two species showing no clear tendency of attraction or repellence. Epigeic species were mostly attracted to the DP treatment.

Two species assigned to the anecic group, Aporrectodea longa (Fig. 2) and Lumbricus friendi, showed a strong tendency towards the DP treatment in Experiment 2 (L. friendi, not shown), while Lumbricus terrestris was not clearly attracted. Statistical analysis showed $A$. longa $\left(\chi_{1}^{2}=1.853, \mathrm{p}>0.05 ; \chi_{2}^{2}=148.879, \mathrm{p}<0.001\right)$ and L. friendi $\left(\chi_{1}^{2}=0, \mathrm{p}=1 ; \chi_{2}^{2}=77.489, \mathrm{p}<0.001\right)$ were significantly attracted to DP treatment in Experiment 2; however, the model fit was low, reported by a very low Akaike information criterion $(\mathrm{AIC}=118)$ compared to other model (AIC $=504$ for the general abundance model Experiment 1).

The two endogeic species attracted to DP treatment were Aporrectodea caliginosa (Fig. 2) $\left(\chi_{1}^{2}=4.865\right.$, $\left.\mathrm{p}<0.05 ; \chi_{2}^{2}=45.446, \mathrm{p}<0.001\right)$ and Allolobophora chlorotica $\left(\chi_{1}^{2}=1.853, \mathrm{p}<0.01 ; \chi_{2}^{2}=176.927, \mathrm{p}<0.001\right)$. Aporrectodea limicola (Fig. 3) and Aporrectodea rosea (Fig. 3) showed no general trend of attraction and therefore the models were not able to cover variability of data and were insignificant. Eiseniella tetraedra and Octolasion cyaneum occurred sporadically only and therefore were not tested statistically.

The epigeic species S. mammalis (Fig. 2) was found in large numbers but almost exclusively under the DP treatment $\left(\chi_{1}^{2}=24.610, \quad \mathrm{p}<0.001 ; \quad \chi_{2}^{2}=94.087\right.$, $\mathrm{p}<0.001$ ). Similarly, the epi-anecic L. festivus (Fig. 2) $\left(\chi_{1}^{2}=30.755, \mathrm{p}<0.001 ; \chi_{2}^{2}=136.710, \mathrm{p}<0.001\right)$, L. castaneus $\left(\chi_{1}^{2}=8.486, \mathrm{p}<0.01 ; \chi_{2}^{2}=49.899, \mathrm{p}<0.001\right)$, and L. rubellus $\left(\chi_{1}^{2}=11.162, \mathrm{p}<0.001 ; \chi_{2}^{2}=35.384, \mathrm{p}<0.001\right)$ appeared mainly under DP treatment with statistically significant treatment effects.

The most attracted species moved towards the DP treatment in the first 2 weeks. Of the anecic species, $A$. longa responded quickly, while $L$. friendi responded with higher abundance under DP at the second sampling. The endogeic species $A$. chlorotica and $A$. caliginosa (Fig. 2) were readily attracted at the first sampling and stayed under DP for more than 11 weeks. The epigeic S. mammalis and the L. castaneus had highest abundances at the second, or third sampling (Fig. 2) and declined thereafter. S. mammalis and the epi-anecic L. festivus were not recorded after 12 weeks or were only marginally present under DP or NDP treatment.

\section{Legacy effect}

General abundance, biomass and juvenile abundance after 27 weeks were comparable between DP and NDP treatments. The overall abundance and juvenile abundance slightly increased compared to the initial NDP sampling, and the biomass was in the range from previous NDP treatments values. Overall abundance measured in Experiment 2 after 27 weeks $(n=5)$ was the same in the DP and NDP treatments (no significant differences) (paired test, $\mathrm{t}_{4}=0.24, \mathrm{p}>0.05$ ), biomass (paired test, $t_{4}=1.19, \mathrm{p}>0.05$ ) and juvenile abundance (paired test, $\left.t_{4}=0.63, p>0.05\right)$. The endogeic group abundance 


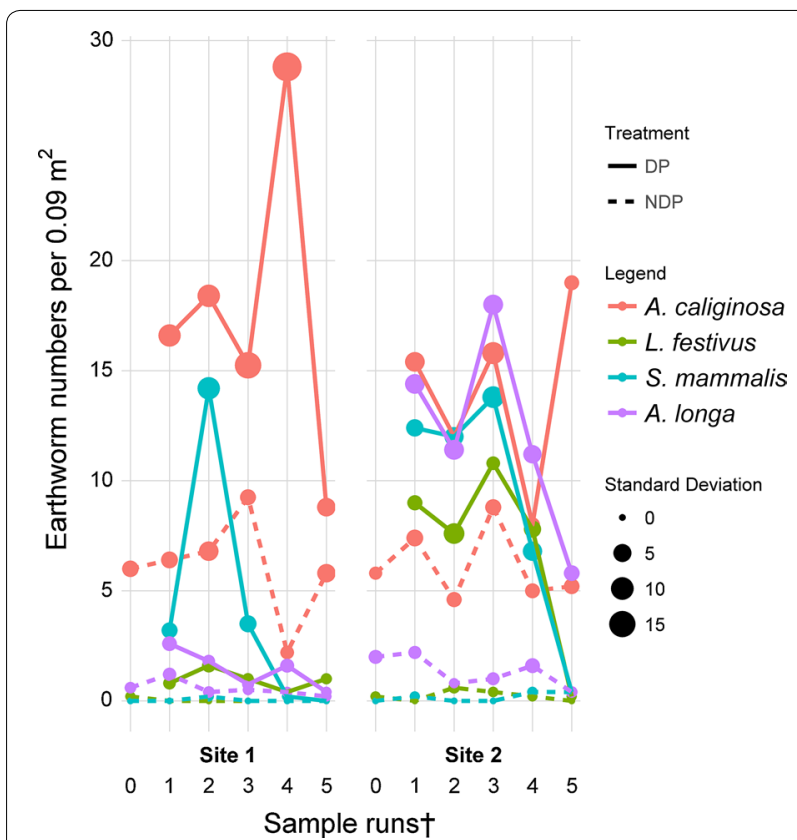

Fig. 2 Selected species aggregating under dung pats. Average earthworm abundance of A. caliginosa (endogeic), L. festivus (epi-anecic), S. mammalis (epigeic) and A. longa (anecic) found per sampling run under dung pats (DP) and non-dung pat treatment (NDP). The size of the points indicates the standard deviation per sampling run. ${ }^{\dagger}$ For sampling dates and intervals, please see Table 2

was the same under the DP and NDP treatments after 27 weeks (mean $\mathrm{DP}=25 \pm 4, \mathrm{NDP}=22 \pm 4$ ); only one species, A. limicola, showed a significantly lower abundance under DP (paired t-test, $\mathrm{t}_{4}=4.4721, \mathrm{p}<0.05$ ) (abundance mean $\mathrm{DP}=4.4 \pm 2.0, \mathrm{NDP}=8.4 \pm 1.1$ ); $A$. longa was not detected and other species of the anecic group generally showed low abundance. Lumbricus castaneus and L. festivus of the epigeic and epi-anecic group were not detected either, while Lumbricus rubellus and $S$. mammalis (Fig. 2) showed only sporadic abundance.

\section{Earthworm community}

The development of the community abundance in relation to time was collapsed into a two-dimensional representation for each experiment (Fig. 4a, b). Each point shows multidimensional distances between the species per each observation. For the DP treatment there was a progressive increase of distance in Dimension 1 with the sample run (red arrow). Sampling run 5 (11 weeks) was observed more distant on Dimension 2 than the earlier runs. Treatment NDP showed no marked trends but was very compact. The extent of the trend of the DP treatment in Dimension 1 was more extensive for Experiment 2 (Fig. 4b) than for Experiment 1.

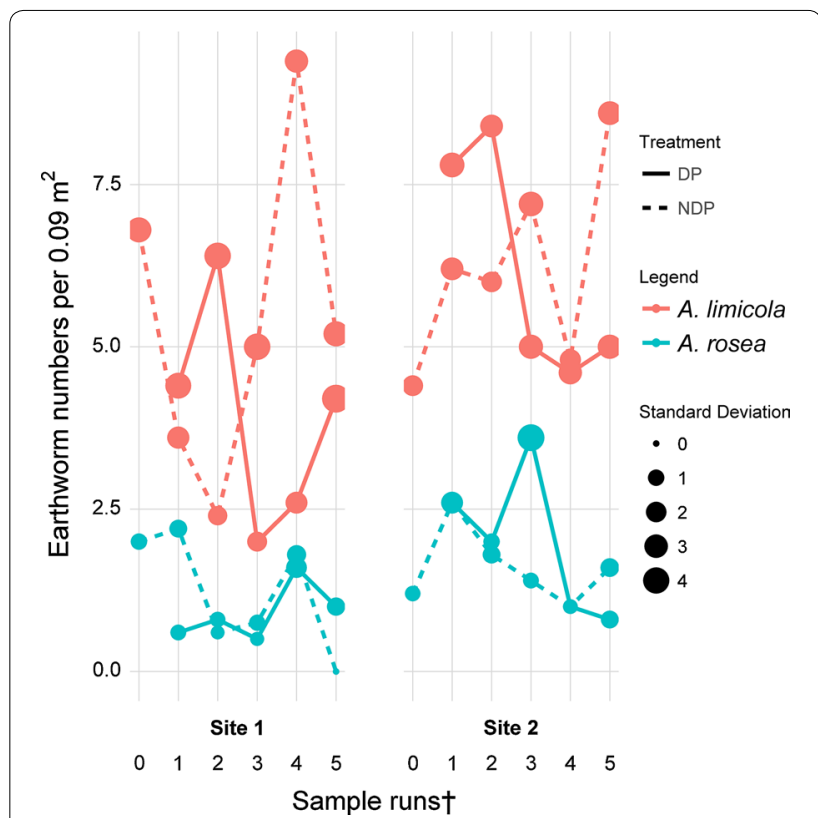

Fig. 3 Species not aggregating under dung pats. Average earthworm abundance of A. limicola (endogeic) and A. rosea (endogeic) found per sampling run under dung pats (DP) and non-dung pat treatment (NDP). The size of the points indicates the standard deviation per sampling run. ${ }^{\dagger}$ For sampling dates and intervals, please see Table 2

\section{Recruitment area}

The calculated earthworm recruitment radius for dung pats for the total abundance, averaged by sampling run, ranged from $0.2 \mathrm{~m}$ to $0.4 \mathrm{~m}$. However, when considering specific species attracted by dung such as the mediumabundant $A$. longa (Fig. 2) the recruitment area increased to up to $0.6 \mathrm{~m}$. For species that had low abundances throughout the pastures such as L. festivus that was even absent from most NDP control samples (see Fig. 2), the calculated radius of the recruitment area was up to $1.1 \mathrm{~m}$.

\section{Discussion}

The study's first hypothesis that spatial earthworm distribution in grasslands is influenced by dung pats was confirmed. The patchy spatial distribution varied also temporally due to differing aggregation and dispersal patterns for individual species, all of which needs to be considered when sampling.

\section{Earthworm species aggregation}

Assessment of earthworm distribution in grazed grasslands needs to specifically take account of aggregation under dung pats. This aggregation effect was shown in both experiments; however, in Experiment 2 considerably higher earthworm abundance and about twice the 


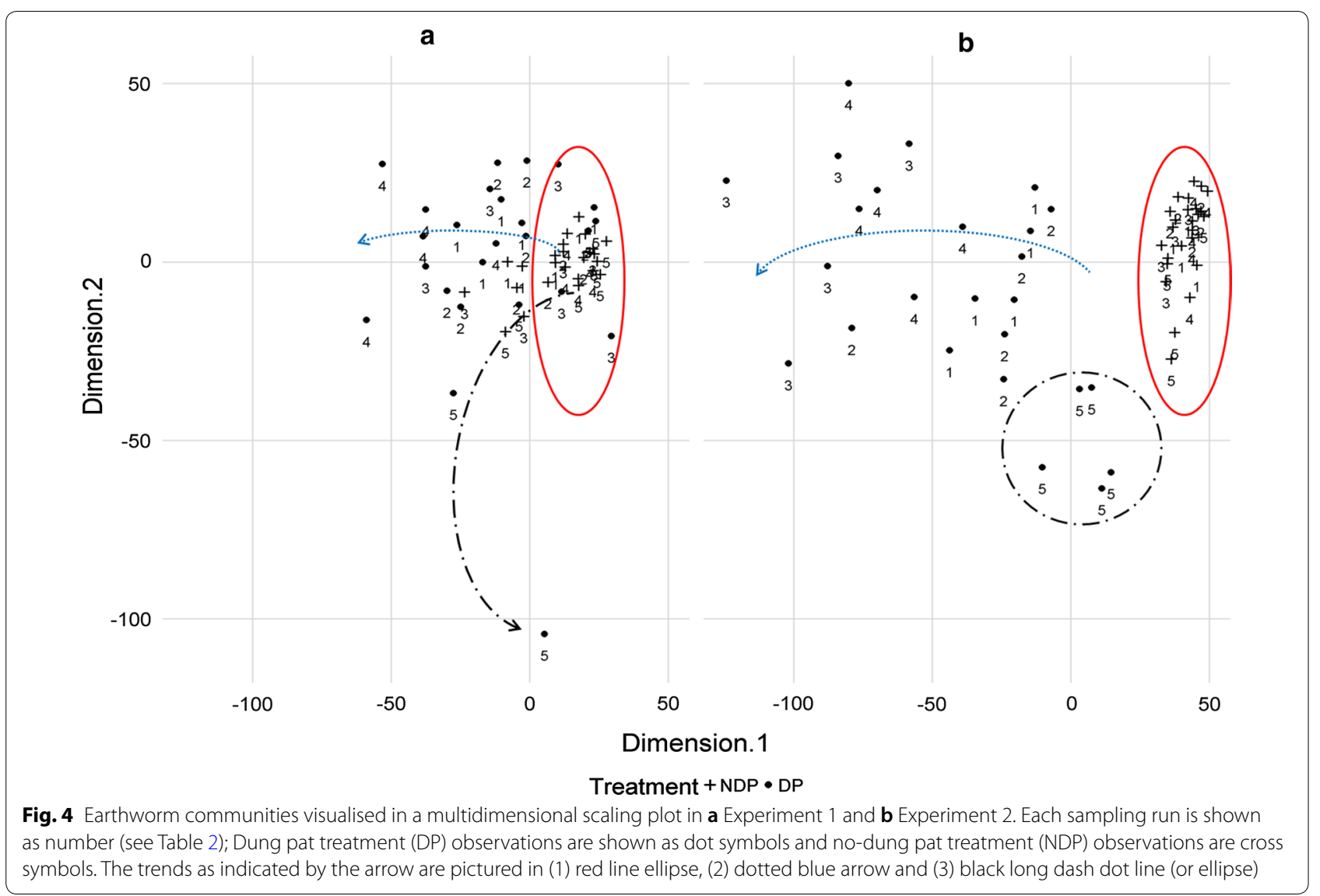

biomass was recorded under the dung pat treatment than in previous studies in U.K. or Denmark [19, 20]. In terms of species distribution, most epigeic species were aggregating under dung, but also certain species of the anecic and endogeic groups were aggregating under dung pats.

The epigeic species commonly associated with dung $[29,30]$ showed strong aggregation under dung pats. In particular, L. castaneus and S. mammalis were nearly exclusively limited to dung locations, reflecting the strong attraction of species of this group to dung pats. $L$. festivus (epi-anecic) (Fig. 2) and the less abundant $L$. rubellus also showed species aggregation.

The endo-anecic designation of $A$. longa (e.g. creation of vertical and horizontal burrows) suggested behavioural flexibility. This explained the results of $A$. longa moving towards and aggregating under dung pats, even though dung was not their first dietary choice in laboratory tests [31]. Aggregation under dung has not been reported before for another species of the anecic group, however in the present study $L$. friendi was attracted to dung pats as well. Aggregation behaviour of the rare species $O$. cyaneum and E. tetraedra in this experiment was not conclusive, however the experimental design and effort were aimed at revealing trends for the most abundant species.
Earthworms are attracted to, and therefore aggregate under dung pats. However, certain species could be attracted but are not horizontally mobile e.g. due to permanent burrows of the anecics. Yet, anecic species can travel to dung pats using even soil surface pathways, as mentioned by Knight et al. [19].

Endogeic species A. chlorotica and A. caliginosa were highly attracted to dung as a food source despite being part of the geophagous group [31]. However, a number of studies [10, 18] assumed that A. chlorotica feeds on incorporated and broken down older dung pats, which does not concur with the present observation that $A$. chlorotica was abundant under relatively intact dung 2 weeks after deposition. Hendriksen [18] did not record attraction to dung pats by $A$. caliginosa but noted variability in the literature in this regard.

\section{Spatial effects}

The observed aggregation of earthworms under the dung pat treatment means that worms had to travel from the surroundings (here termed 'recruitment area') to accumulate under dung pat positions. The estimated recruitment radii of certain species of up to $1.1 \mathrm{~m}$ around each dung pat highlights the spatial importance of dung pats 
at field scale. Mainly for the purpose of greenhouse gas emission research, various studies assessed [32-34] and modelled $[35,36]$ the extent of grazing cow excreta deposition. It has been estimated that a cow produces 8-12 dung pats a day [36] with an average area of $0.05 \mathrm{~m}^{2}$ [33, 34]. Based on these assumptions and the management of Experiment 1, during 6 weeks' grazing, cows would deposit about 300 dung pats per ha covering directly an area of only $15 \mathrm{~m}^{2}$. However, when earthworm abundance was at its peak, the respective recruitment radius considering a single abundant species e.g. L. festivus was $1.1 \mathrm{~m}$ for each of these dung pats. This, in turn, would translate into a $3.8 \mathrm{~m}^{2}$ earthworm influence/recruitment area for each dung pat; however, when multiplied by total pat number, to an area of $1140 \mathrm{~m}^{2}$ or about $11 \%$ of the total grazing area. Furthermore, since dung pats are deposited repeatedly over time during a grazing season, an even larger influence/recruitment area appears likely until dung pats are completely degraded.

This simple extrapolation emphasizes the likely impact of dung pats on the distribution of earthworms in grazed grasslands. Accounting for this impact by spatial assessment is important in any earthworm study in such systems. Present calculations suggest that certain earthworm species might travel at least $1 \mathrm{~m}$; however, published studies describing patchy earthworm species distribution at larger scales $[13,27,28]$ suggests that further travel distances to reach favourable spots such as dung pats are likely.

\section{Temporal effects}

The second hypothesis, regarding temporal arrival and dispersal patterns, was partly confirmed by species moving towards the dung pat in the first 2 weeks; yet, no clear successional response was observed. Knight et al. [19] observed that attraction can occur earlier i.e. within the first 4 days of dung pat deposition. That could be one reason why an obvious successional response to dung pat attraction was generally not observed here because all but $L$. friendi species attracted to dung showed an increased abundance under dung from the first sampling run onwards; competing species with correspondingly decreasing abundance were not identified. Expected successional pattern involving $A$. chlorotica following L. rubellus as identified by Murchie et al. [10] was not observed: A. chlorotica (also A. caliginosa) aggregated already at the first sampling run. However, the experimental design did not allow for examination of this trend before the first sampling. Therefore competition among species for the ephemeral food source as indicated for other dung organisms [37] was not observed. Instead of species succession, L. castaneus and S. mammalis showed coexisting behaviour by following similar aggregation and redispersal pattern (in Experiment $1 \mathrm{~L}$. castaneus seemed to be one sampling run delayed) from dung pats.

\section{Legacy effect}

The total and juvenile abundance and total biomass observed after 27 weeks did not support the third hypothesis that dung pats have a legacy effect after full degradation. A possible longer-term effect of dung pats on earthworm distributions for over 3 months was discussed by Herrick and Lal [38] for tropical soils. However, the present results based on one sampling date 6 months after dung deposition suggest that anecic and endogeic species did not show a clear preference between previous dung pat locations and no-dung control spots, while epigeic species were largely absent in April, likely due to seasonality [20].

\section{Earthworm community}

The nonmetric multidimensional scaling (nMDS) is used to present ecological effects and communities [39-41]. Up to here earthworm species were discussed separately and over time, whereas nMDS provides an integrated analysis of spatial and temporal trends of the community. The nMDS plot (Fig. 4) illustrates the aggregation of earthworms under dung pats in time, where Dimension 1 can be interpreted as species diversity developing over time, while Dimension 2 somewhat reflected resource exhaustion. In the present study trends were observed, similar to Slade et al. [42] who studied microbial communities associated with dung beetle presence, in relation to dung degradation. Earthworm communities of dung pat and non-dung pat treatments were similar at the beginning, which can be also observed in Slade et al. [42] at the 12 days stage. Communities/treatments diverged then further apart but became eventually more similar. They ended up less distinguishable, agreeing with the more homogenous microbial communities in Slade et al. [42]. Experiment 2 showed a greater spread and distance between treatments and sample runs, which might be caused by more significant differences between treatments by larger earthworm numbers in general. The nMDS plot (Fig. 4) supported the suggestion that controlled conditions in Experiment 2 provided more robust data.

\section{Implications for earthworm population assessments}

To assess earthworm populations, the spatial and temporal aggregation effect of ephemeral resources such as dung pats or droppings has to be considered. Results from the present and previous studies suggest 
strongly that, in grazed grasslands, earthworm sampling approaches should consider such effects that lead to patchiness of earthworm species on the field scale [5].

Studies on grassland management practices and earthworm abundance that do not consider the above may fall short in terms of reliability of their findings. Studies that compared earthworm populations or distribution of grazed and non-grazed grasslands such as Epelde et al. [6] found a more diverse earthworm community in grassland when grazing was stopped. Similarly, Schlaghamerský et al. [7] compared grazed with mowed grassland sites and found significantly fewer earthworms in grazed grasslands. However, the reported sampling design used could have underestimated earthworm abundances, or even missed specific species such as $S$. mammalis or $L$. castaneus. Comparing the present results with those of Schlaghamerský et al. [7] indicates that most of the species that were less abundant or absent in two of the three pastures of the observed pasture-grassland combinations in Schlaghamerskýs study were highly aggregated below the present dung pat treatment. In another example, Ponge [43] concluded possibly negative effects of higher grazing intensity on soil macro-invertebrate communities without particularly considering the aggregation of earthworms under dung pats. Earlier studies examining the potential of modelling the distribution and abundance of earthworm species in grasslands e.g. A. caliginosa did not consider dung pat presence [25]. Reliability of such studies could be improved by combining them with spatial dung pat application models such as that by Yoshitoshi et al. [36].

It is eminently clear from this and previous studies that deliberate sampling away from dung pat areas will likely underestimate some earthworm species or even completely miss specific species such as $S$. mammalis or $L$. castaneus in biodiversity assessments. This is an important point to make for future studies of grazed grassland, grazing intensity gradients or grazing versus non-grazing managements. The following recommendations are offered for such studies:

1. Visually assess dung pat presence and age (consult grazing management records, talk to farmer) on site in question or within a relevant range around the site.

2. Include a minimum or proportional number of dung pat affected locations in the sampling plan. If dung pats are absent at a target site at time of sampling, but present in the vicinity of the site, some dung pats could be sampled qualitatively to determine the absence/presence of ecological groups and species for the site.

\section{Conclusions}

This study addressed knowledge gaps in relation to the behaviour of earthworms towards cattle dung pats in grazed grassland. The study showed that dung pat attraction has temporal and spatial dimensions and that earthworm responses are species specific. The presence of dung pats in pastures creates spatial earthworm species distributions that change with dung pat age. These findings highlight that it is important to consider dung pats, temporally and spatially, when sampling earthworms in grazed pastures and in grasslands with wild mammalian grazers. Published comparisons of grazed and cut grasslands probably came to incorrect conclusions by ignoring or deliberately avoiding dung pats. Furthermore, the observed intense aggregation of earthworms beneath dung pats suggests that earthworm functions need to be assessed separately at these hot spots. Such research is likely to produce more nuanced insights into earthworms as ecosystem engineers that are of wide interest to researchers, farmers and the general public.

\section{Methods \\ Field sites}

Two different field-sites (Site 1 and Site 2), located on the dairy research farm of Teagasc, Johnstown Castle, Co. Wexford, Ireland, were selected as representative of intensively managed, permanent grassland. The study area has a mean daily temperature of $9.6^{\circ} \mathrm{C}$ and a mean annual precipitation of $1000 \mathrm{~mm}$ (effective precipitation is $\sim 500 \mathrm{~mm}$ ) [44]. Air and soil temperature along with precipitation were recorded by the national synoptic weather station situated within the same research centre (within $1 \mathrm{~km}$ of both sites) (Fig. 5). Soil moisture deficit (SMD) was estimated using the hybrid grassland model of Schulte et al. [45] based on weather station inputs and assigning a soil drainage class for each site. Two different experiments were carried out: Experiment 1 on site 1 and Experiment 2 on site 2, respectively. Prior to the experiments, intact cores $(n=3)$ were taken at random to determine bulk density $\left(\rho_{\mathrm{b}}\right)$ [46] and particle size distribution (PSD\%) determined by the pipette method [47] of the sites at 5-10 and $10-20 \mathrm{~cm}$ depth (core volume $100 \mathrm{~cm}^{3}$ ) for Experiment 1 , and at $5-10 \mathrm{~cm}$ and $20-25 \mathrm{~cm}$ for Experiment 2 (volume $250 \mathrm{~cm}^{3}$ ) (Table 1 ).

Site 1 Field work at site 1 (0.8 ha, 52.293472, -6.493222 ) took place during spring 2015. For this site elevation is $60 \mathrm{~m}$ above ordnance datum (m AOD), on a slightly sloped (1\%) plain with a south-south-west aspect. The moderately drained soil was classified as 

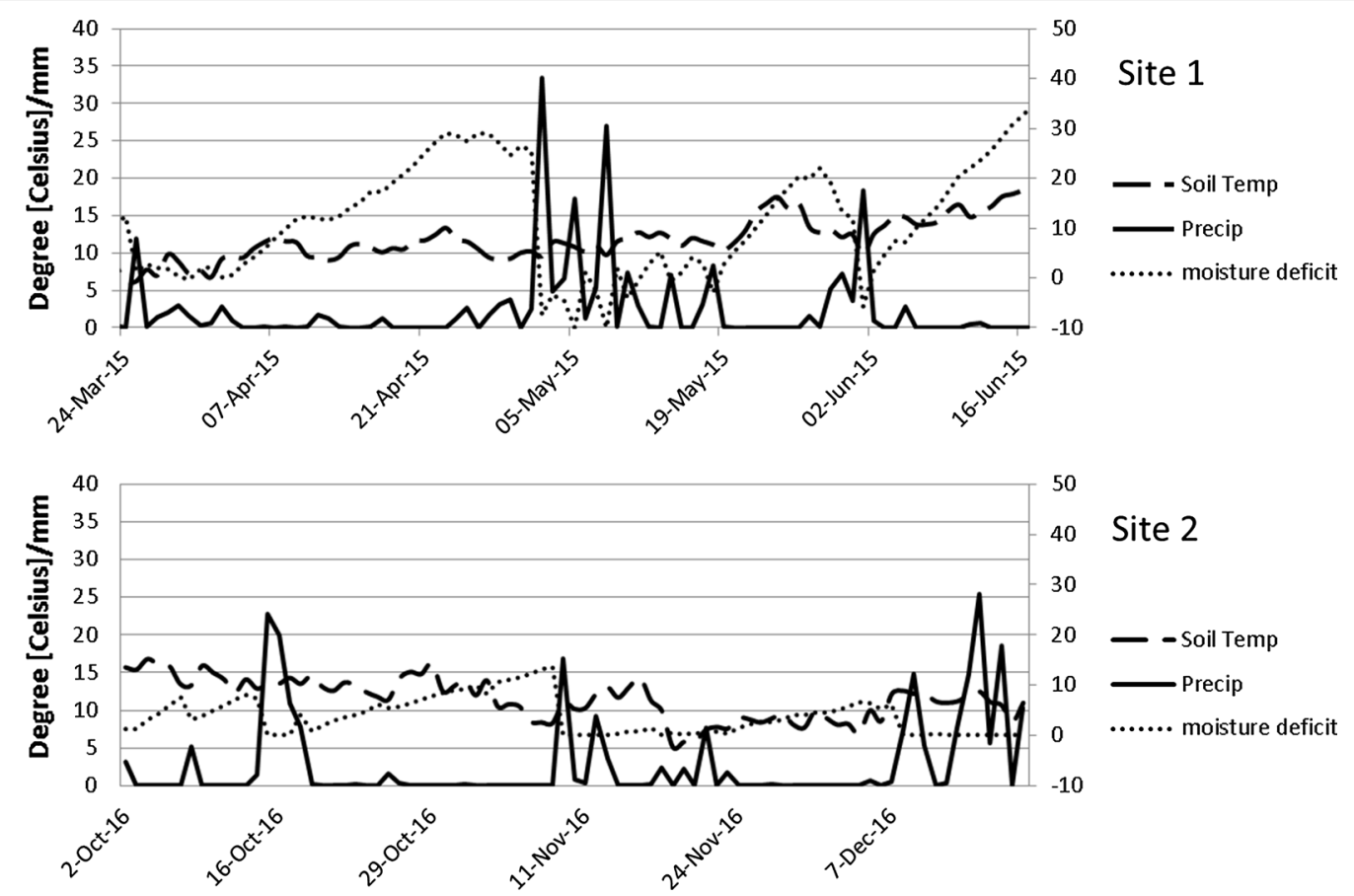

Fig. 5 Environmental variables measured on the $y$-axis (soil temperature, precipitation) or estimated on the alternative $y$-axis (soil moisture deficit) at the local weather station with dates on the $x$-axis during Experiment 1 (a) and Experiment 2 (b)

Table 1 Soil physical properties $(n=3)$ for both sites

\begin{tabular}{|c|c|c|c|c|c|}
\hline & \multirow{2}{*}{$\begin{array}{l}\text { Depth } \\
(\mathrm{cm})\end{array}$} & \multicolumn{2}{|l|}{ PSD\% } & \multirow[b]{2}{*}{ Clay $<0.002 \mathrm{~mm}$} & \multirow{2}{*}{$\begin{array}{l}\text { Bulk } \\
\text { density } \\
\mathrm{Mg} \mathrm{m}^{-3}\end{array}$} \\
\hline & & $\begin{array}{l}\text { Sand } \\
2-0.05 \mathrm{~mm}\end{array}$ & $\begin{array}{l}\text { Silt 0.05- } \\
0.002 \mathrm{~mm}\end{array}$ & & \\
\hline \multirow[t]{2}{*}{ Site 1} & $5-10$ & 68.3 & 18.7 & 13.0 & $1.31(0.11)$ \\
\hline & $10-20$ & $n / a$ & $\mathrm{n} / \mathrm{a}$ & $\mathrm{n} / \mathrm{a}$ & $1.44(0.02)$ \\
\hline \multirow[t]{2}{*}{ Site 2} & $5-10$ & 64.4 & 21.8 & 13.7 & $1.22(0.17)$ \\
\hline & $20-25$ & 66.2 & 18.6 & 15.2 & $1.46 \mathrm{n} / \mathrm{a}$ \\
\hline
\end{tabular}

stagnic brown earth [48] corresponding to a stagnic cambisol in WRB [49] classification. Soil texture is sandy loam in top and subsoil $(20-25 \mathrm{~cm})$. Old red sandstone bedrock is at $15 \mathrm{~m}$ depth with average water table position at approximately $2.5 \mathrm{~m}$. The site had been under permanent pasture at least since 2000 with occasional silage cutting and was reseeded in 2008. Intense rotational strip grazing was performed since 2012 with a stocking rate of $1.98 \mathrm{LU} \mathrm{ha}^{-1}$ in 2014 (1 Livestock Unit $=1$ dairy cow), starting usually in February/March with a 21 day cycle from April to late August/September and then extended to 40 days until October/early November. The site had not been grazed in 2015 before the start of the present experiment. No pesticides or organic fertilizers such as slurry were applied during the experiment, but inorganic fertilizer was applied as shown in Additional file 1. No lime had been applied since 2008. A sward assessment showed predominantly perennial rye grass (Lolium perenne).

Site 2 Field work at site $2(0.6$ ha, 52.29982, -6.50617) took place during autumn 2016. The site elevation is $80 \mathrm{~m}$ AOD, close to the top of a hill and slightly sloped (7\%) facing south-south-west. The moderately-drained soil was classified as stagnic brown podzolic [48] which corresponds to a stagnic Podzol within the WRB [49] classification system. The soil texture classification of the top soil and subsoil is sandy loam. Bedrock of Cambrian greywacke is at $10 \mathrm{~m}$ depth with an average water table position at $2.5 \mathrm{~m}$ depth. The site had not been reseeded since 2007. The management history was regular silage cutting and occasional grazing by dry stock up to 50 days per year with a stocking rate of $1.71 \mathrm{LU} \mathrm{ha}^{-1}$ in 2015 . The site had not been grazed for the 2016 season and grass was cut before the start of the present experiment. No pesticides or organic fertilizers were applied. Nutrient inputs as inorganic fertilizer are presented in Additional file 1. In 2013, $4.3 \mathrm{t} \mathrm{ha}^{-1}$ of calcium lime was applied. A pre-experimental sward assessment showed predominantly perennial ryegrass (Lolium perenne), annual meadow grass (Poa annua), bent grass (Agrostis family), meadow fox-tail (Alopecurus pratensis), and mouse-ear chickweed (Cerastium fontanum). 


\section{Experimental designs}

The experimental designs comprised of naturally deposited cattle dung pats in Experiment 1 and simulated, randomly distributed dung pats in Experiment 2. The two treatments for earthworm sampling were DP: Dung pat treatment, and NDP: No-dung pat treatment (control). Earthworm sampling was conducted (i) at the start of the experiments before dung pat deposition/application; and (ii) over the full life time of dung pats, i.e. from dung deposition/application until disappearance. Sampling was carried out at five dates, once every 2 weeks and 5 spatial replicates were taken on each date for each treatment. To study the influence of soil moisture trends, gravimetric water content was determined at each sampling run following the procedure of Schmidt and Curry [50], whereby a soil sample of $100 \mathrm{~g}$ was taken from a depth of $5-15 \mathrm{~cm}$ and oven dried at $105^{\circ} \mathrm{C}$ for $24 \mathrm{~h}$ and the weight change recorded.

\section{Design Experiment 1}

The pasture was initially grazed for 4 days in the end of March 2015. Dung pats were naturally deposited by dairy cows at $15.1 \mathrm{LU}$ ha day ${ }^{-1}$ stocking rate (4 days, i.e. each day, one quarter grazed). Thereafter, livestock grazing was avoided during the experiment. Then, 25 dung pats with an approximate diameter of $30 \mathrm{~cm}$ were selected and numbered. To avoid field border effects [51], a $10 \mathrm{~m}$ margin at the borders of the field was not used. The GPS position of each dung pat was recorded using a Trimble Pathfinder Pro GPS (Trimble Navigation Limited, California, USA) and marked with a magnet to track the location once degradation occurred. For each sampling run a stratified-random pat selection was followed by sampling every fifth DP treatment point. NDP sampling points were selected using a grass area half way between two DP points (see Additional file 2). Distances between dung pats and control plot measurements were at least $10 \mathrm{~m}$. Earthworm sampling was carried out the same way for both experiments (see "Earthworm sampling" section), but due to slow infiltration with no earthworms emerging for two consecutive sampling runs, the allyl isothiocyanate (AITC) treatment was discontinued for Experiment 1.

\section{Design Experiment 2}

Fresh solid dung was collected in September 2016 from dairy cows in the yard and nearby dairy fields over a number of days, avoiding urine and fresh grass residues. Dung was stored at $4{ }^{\circ} \mathrm{C}$ for up to 2 weeks and then mixed and homogenised using a drywall mixer. Simulated dung pats (DP treatment) were applied on 3rd of October using a defined fresh weight $(2 \mathrm{~kg})$ of dung. Each dung pat had a defined diameter of $30 \mathrm{~cm}$. Dung pats were placed on a plastic mesh (10 mm mesh size) on short mown grass sward, pressed down by their own weight and covered with chicken wire for bird protection. Dung pats were placed in a randomized block design with five blocks (Additional files 2 and 3) each block containing six temporal replicates of the DP treatment and NDP treatment and additional measurements. The distances between sampling blocks were at least $2 \mathrm{~m}$ but usually greater (Additional file 3). Sampling intervals were timed as for Experiment 1; however, an additional sampling run was carried out after 6 months (10th April 2017) to test for dung legacy effects (see Table 2).

\section{Earthworm sampling}

To sample under dung pats, the dung pat was visually inspected for earthworms and occurring worms were extracted, then the dung was scratched or lifted off the soil surface. Then, a block of soil of $30 \mathrm{~cm} \times 30 \mathrm{~cm} \times 25 \mathrm{~cm}$ depth $\left(0.023 \mathrm{~m}^{3}\right)$ was extracted, broken up and manually sorted for earthworms. Handsorting was the method of choice to investigate dung effects, however it is known that the relatively small sampling area is less suitable for estimating adult anecic

Table 2 Timing of dung pat applications and sampling runs, shown as dates and time elapsed since dung application

\begin{tabular}{|c|c|c|c|c|}
\hline \multirow[t]{2}{*}{ Sampling run } & \multicolumn{4}{|c|}{ Days before or after dung application } \\
\hline & Days (weeks) & Experiment 1 & Days (weeks) & Experiment 2 \\
\hline Initial pre-dung sampling & $-4(-1)$ & $24 / 3 / 2015$ & $-1(0)$ & $02 / 10 / 2016$ \\
\hline Dung pat application & $0(0)$ & 28/03/2015 & $0(0)$ & 03/10/2016 \\
\hline Run 1 & $14(2)$ & $10 / 04 / 2015$ & $15(2)$ & $17 / 10 / 2016$ \\
\hline Run 2 & $27(4)$ & 23/04/2015 & $28(4)$ & $01 / 11 / 2016$ \\
\hline Run 3 & $41(6)$ & 07/05/2015 & $51(7)$ & $22 / 11 / 2016$ \\
\hline Run 4 & $55(8)$ & $21 / 05 / 2015$ & $64(9)$ & $05 / 12 / 2016$ \\
\hline Run 5 & $80(11)$ & $15 / 06 / 2015$ & $76(11)$ & $17 / 12 / 2016$ \\
\hline Legacy effect run & $\mathrm{n} / \mathrm{a}$ & $\mathrm{n} / \mathrm{a}$ & $190(27)$ & $10 / 04 / 2017$ \\
\hline
\end{tabular}


earthworms [50, 51]. An allyl isothiocyanate (AITC) $\left(100 \mathrm{mg} \mathrm{L}^{-1}\right)$ solution was poured into the pit to extract earthworms from deeper subsoil layers [52, 53]. Earthworms were collected into a moistened jar, kept in the shade and preserved in formaldehyde solution (4\%).

\section{Earthworm identification}

After 8 weeks earthworms were transferred from formaldehyde into $70 \%$ industrial methylated spirit for long time storage. Preserved earthworms per sample replicate were blotted dry and weighed (to $0.01 \mathrm{~g}$ ) on a precision laboratory scale PM200 (Mettler-Toledo LLC, Columbus, OH, USA) to determine the earthworm biomass (with gut content). Mature and sub-adult individuals were identified to species level, juveniles were separated into epilobic un-pigmented, epilobic pigmented and tanylobic earthworms and fragments were recorded separately. An S8APO microscope (Leica Microsystems GmbH, Wetzlar, Germany) and the key by Sims and Gerard [54] were used for identification. Taxonomy follows Sims and Gerard [54].

\section{Spatial calculations}

The potential recruitment area (from where earthworms moved towards a dung pat) was calculated as a recruitment radius using Eq. 1 . Total numbers under a dung pat were assumed to be the sum of numbers under grass and the difference having moved in from the surrounding recruitment radius (measured from the centre of the dung pat). In some sampling runs the abundance of certain species under grass was zero, and in such cases the average of that species under grass during the whole experiment was used instead.

$$
r=\sqrt{\frac{A_{p}}{A_{g}} \frac{p}{\pi}}
$$

where recruitment radius $r$, the dung pat area $p$, the earthworm abundance under the pat $\mathrm{A}_{\mathrm{p}}$, and the abundance under grass $\mathrm{A}_{\mathrm{g}}$.

\section{Statistical analysis}

The data were analysed as a factorial combination of treatment (2 levels) and sample run (5 dates). Due to a number of conditions varying between the two experiments (i.e. different site, different year/season, naturally deposited versus simulated dung pats), results were examined separately. The earthworm count data were analysed using a negative binomial model to allow for over-dispersion relative to a Poisson model.
The analysis was fitted using the glm.nb function in $\mathrm{R}$ [55]. The presence of over-dispersion and residual plots were assessed to ensure that the assumptions of the analysis were met. A type three analysis of deviance (ANOVA) with Chi square test of independence was performed to examine the effect of the treatment. Predicted means were used to compare levels of significant effects. A mixed effect model accounting for the randomized block design applied for Experiment 2 data was used to test for block effects. Sampling runs 1-5 available for both experiments were analysed with the same methods, while the sixth sampling run (Site 2 only) was treated separately. A least square mean comparison applying the Tukey test using the packages lsmeans [56] was used to identify influence of sampling runs on total abundance and species. The development of earthworm communities was assessed using a visualisation based on nonmetric multi-dimensional scaling (nMDS) [57]. The distances between observations consisting of a set of species and each sampling run, in a high dimensional space, was calculated. The nMDS algorithm then plotted the observations in an nMDS plot where distances are represented in an approximate way in 2 dimensions.

\section{Additional files}

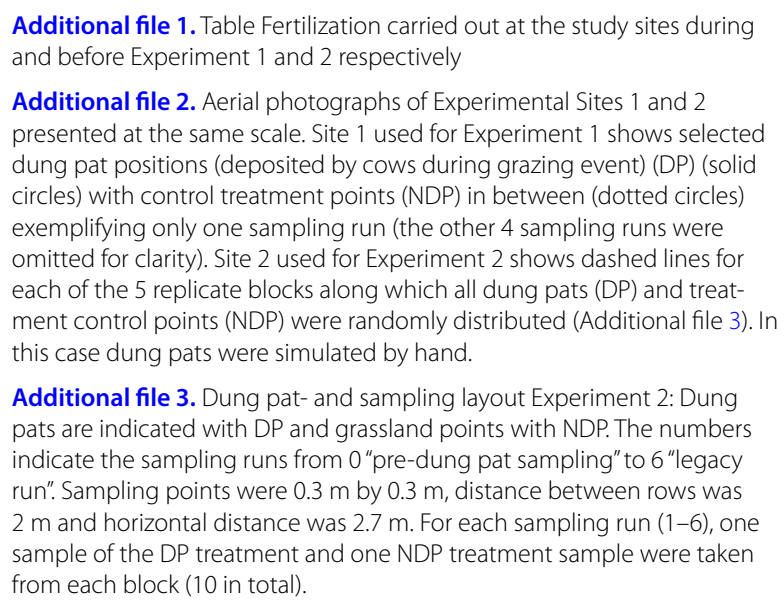

Additional file 2. Aerial photographs of Experimental Sites 1 and 2 presented at the same scale. Site 1 used for Experiment 1 shows selected dung pat positions (deposited by cows during grazing event) (DP) (solid circles) with control treatment points (NDP) in between (dotted circles) exemplifying only one sampling run (the other 4 sampling runs were omitted for clarity). Site 2 used for Experiment 2 shows dashed lines for each of the 5 replicate blocks along which all dung pats (DP) and treatment control points (NDP) were randomly distributed (Additional file 3). In this case dung pats were simulated by hand.

Additional file 3. Dung pat- and sampling layout Experiment 2: Dung pats are indicated with DP and grassland points with NDP. The numbers indicate the sampling runs from 0 "pre-dung pat sampling" to 6"legacy run". Sampling points were $0.3 \mathrm{~m}$ by $0.3 \mathrm{~m}$, distance between rows was $2 \mathrm{~m}$ and horizontal distance was $2.7 \mathrm{~m}$. For each sampling run (1-6), one sample of the DP treatment and one NDP treatment sample were taken from each block (10 in total).

\section{Authors' contributions}

MGB, OF, RC and OS designed the study; MGB and GB conducted fieldwork; MGB and MK identified samples; MGB analyzed the data; MGB, GB, OF and OS wrote the manuscript. All authors read and approved the final manuscript.

\section{Author details}

${ }^{1}$ Teagasc, Environment Research Centre, Wexford, Ireland. ${ }^{2}$ UCD School of Agriculture and Food Science, University College Dublin, Dublin 4, Ireland. ${ }^{3}$ Soil Biology Group, Wageningen University, Wageningen, The Netherlands.

${ }^{4}$ UCD Earth Institute, University College Dublin, Belfield, Dublin 4, Ireland. 


\section{Acknowledgements}

The authors thank all helpers sampling earthworms, Jim Grant for the statistics advice and Simon Leach for providing the aerial photographs.

\section{Competing interests}

The authors declare that they have no competing interests.

\section{Availability of data and materials}

The datasets generated and analysed during the current study are not publicly available until the full SQUARE dataset will be released, however, they may be available from the corresponding author on reasonable request.

\section{Consent for publication}

Not applicable.

\section{Ethics approval and consent to participate}

Not applicable.

\section{Funding}

This work formed part of the SQUARE Project, funded by the Irish Department of Agriculture, Food and the Marine (Ref. 13/S/468).

\section{Publisher's Note}

Springer Nature remains neutral with regard to jurisdictional claims in published maps and institutional affiliations.

Received: 28 June 2018 Accepted: 12 December 2018 Published online: 19 December 2018

\section{References}

1. Suttie JM, Reynolds SG, Batello C, editors. Grasslands of the world. Rome, Food and Agriculture Organization of the Untited Nations; 2005. p. 514.

2. Alexandratos N, Bruinsma J. World agriculture towards 2030/2050: the 2012 revision. ESA Working paper No. 12-03. Rome: FAO; 2012.

3. Plantureux S, Peeters A, McCracken D. Biodiversity in intensive grasslands: effect of management, improvement and challenges. Agron Res. 2005;3:153-64.

4. O'Mara FP. The role of grasslands in food security and climate change. Ann Bot. 2012;110:1263-70.

5. Mikola J, Setälä H, Virkajärvii P, Saarijärvi K, IImarinen K, Voigt W, et al. Defoliation and patchy nutrient return drive grazing effects on plant and soil properties in a dairy cow pasture. Ecol Monogr. 2009;79:221-44.

6. Epelde L, Lanzén A, Mijangos I, Sarrionandia E, Anza M, Garbisu C. Short-term effects of non-grazing on plants, soil biota and abovegroundbelowground links in Atlantic mountain grasslands. Sci Rep. 2017;7:15097.

7. Schlaghamerský J, Šídová A, Pižl V. From mowing to grazing: does the change in grassland management affect soil annelid assemblages? Eur J Soil Biol. 2007:43:72-8.

8. Curry JP, Doherty P, Purvis G, Schmidt O. Relationships between earthworm populations and management intensity in cattle-grazed pastures in Ireland. Appl Soil Ecol. 2008;39:58-64.

9. Cluzeau D, Binet F, Vertes F, Simon JC, Riviere JM, Trehen P. Effects of intensive cattle trampling on soil-plant-earthworms system in two grassland types. Soil Biol Biochem. 1992;24:1661-5.

10. Murchie AK, Blackshaw RP, Gordon AW, Christie P. Responses of earthworm species to long-term applications of slurry. Appl Soil Ecol. 2015;96:60-7

11. Jouquet $P$, Huchet $G$, Bottinelli N, Thu TD, Duc TT. Does the influence of earthworms on water infiltration, nitrogen leaching and soil respiration depend on the initial soil bulk density? A mesocosm experiment with the endogeic species Metaphire posthuma. Biol Fertil Soils. 2012;48:561-7.

12. Cannavacciuolo M, Bellido A, Cluzeau D, Gascuel C, Trehen P. A geostatistical approach to the study of earthworm distribution in grassland. Appl Soil Ecol. 1998;9:345-9.

13. Valckx J, Govers G, Hermy M, Muys B. Optimizing earthworm sampling in ecosystems. In: Karaca Ayten, editor. Biology of earthworms. Berlin: Springer; 2011. p. 19-39.
14. White R, Murray S, Rohweder M. Pilot analysis of global ecosystems: Grassland ecosystems. Washington, DC: World Resources Institute; 2000.

15. James SW. Localized dynamics of earthworm populations in relation to bison dung in north American tallgrass prairie. Soil Biol Biochem. 1992;24:1471-6.

16. Macci C, Doni S, Bondi G, Davini D, Masciandaro G, Pistoia A. Effects of wild boar (Sus scrofa) grazing on soil properties in Mediterranean environment. CATENA. 2012;98:79-86.

17. Holter P. Effect of dung-beetles (Aphodius spp) and earthworms on the disappearance of cattle dung. Oikos. 1979;32:393-402.

18. Hendriksen NB. Consumption and utilization of dung by detritivorous and geophagous earthworms in a Danish pasture. Pedobiologia. 1991;35:65-70.

19. Knight D, Elliott PW, Anderson JM, Scholefield D. The role of earthworms in managed, permanent pastures in Devon, England. Soil Biol Biochem. 1992;24:1511-7.

20. Svendsen TS, Grønvold J, Holter P, Sommer C. Field effects of ivermectin and fenbendazole on earthworm populations and the disappearance of dung pats from bolus-treated cattle. Appl Soil Ecol. 2003;24:207-18.

21. Baker G, Buckerfield J, Grey-Gardner R, Merry R, Doube B. The abundance and diversity of earthworms in pasture soils in the Fleurieu Peninsula, South Australia. Soil Biol Biochem. 1992;24:1389-95.

22. Boag B, Palmer LF, Neilson R, Legg R, Chambers SJ. Distribution, prevalence and intensity of earthworm populations in arable land and grassland in Scotland. Ann Appl Biol. 1997;130:153-65.

23. Didden WAM. Earthworm communities in grasslands and horticultural soils. Biol Fertil Soils. 2001;33:111-7.

24. Baker GH, Lee KE. Earthworms. In: Carter MR, editor. Soil sampling and methods of analysis. Boca Raton: Lewis Publishers; 1993. p. 359-71.

25. Palm J, van Schaik NLMB, Schröder B. Modelling distribution patterns of anecic, epigeic and endogeic earthworms at catchment-scale in agroecosystems. Pedobiologia. 2013;56:23-31.

26. Brown GG, Barois I, Lavelle P. Regulation of soil organic matter dynamics and microbial activity in the drilosphere and the role of interactions with other edaphic functional domains. Eur J Soil Biol. 2000;36:177-98.

27. Rossi J-P, Nuutinen $V$. The effect of sampling unit size on the perception of the spatial pattern of earthworm (Lumbricus terrestris L.) middens. Appl Soil Ecol. 2004;27:189-96.

28. Rossi J. Short-range structures in earthworm spatial distribution. Pedobiologia. 2003;47:582-7.

29. Curry JP, Schmidt O. The feeding ecology of earthworms-a review. Pedobiologia. 2007;50:463-77.

30. O'Hea NM, Kirwan L, Finn JA. Experimental mixtures of dung fauna affect dung decomposition through complex effects of species interactions. Oikos. 2010;119:1081-8.

31. Doube BM, Schmidt O, Killham K, Correll R. Influence of mineral soil on the palatability of organic matter for lumbricid earthworms: a simple food preference study. Soil Biol Biochem. 1997;29:569-75.

32. Allen AG, Jarvis SC, Headon DM. Nitrous oxide emissions from soils due to inputs of nitrogen from excreta return by livestock on grazed grassland in the UK. Soil Biol Biochem. 1996;28:597-607.

33. Lantinga E, Keuning JA, Groenwold J, Deenen PJ. Distribution of excreted nitrogen by grazing cattle and its effects on sward quality, herbage production and utilization. In: van der Meer HG, et al., editors. Animal manure on grassland and fodder crops. Dordrecht: Martinus Nijhoff Publishers; 1987. p. 103-17.

34. MacLusky DS. Some estimates of the areas of pasture fouled by the excreta of dairy cows. Grass Forage Sci. 1960;15:181-8.

35. Hutchings NJ, Olesen JE, Petersen BM, Berntsen J. Modelling spatial heterogeneity in grazed grassland and its effects on nitrogen cycling and greenhouse gas emissions. Agric Ecosyst Environ. 2007;121:153-63.

36. Yoshitoshi R, Watanabe N, Yasuda T, Kawamura K, Sakanoue S, Lim J, et al. Methodology to predict the spatial distribution of cattle dung using manageable factors and a Bayesian approach. Agric Ecosyst Environ. 2016;220:135-41.

37. Finn JA, Gittings T. A review of competition in north temperate dung beetle communities. Ecol Entomol. 2003;28:1-13.

38. Herrick JE, Lal R. Soil physical property changes during dung decomposition in a tropical pasture. Soil Sci Soc Am J. 1995;59:908-12.

39. Thakuria D, Schmidt O, Finan D, Egan D, Doohan FM. Gut wall bacteria of earthworms: a natural selection process. ISME J. 2010;4:357-66. 
40. Schmidt O, Keith AM, Arroyo J, Bolger T, Boots B, Breen J, et al. The CréBeo soil biodiversity project. Johnstown Castle Estate Co. Wexford: Environmental Protection Agency; 2011.

41. Somerfield PJ, Clarke KR. Inverse analysis in non-parametric multivariate analyses: distinguishing groups of associated species which covary coherently across samples. J Exp Mar Bio Ecol. 2013;449:261-73.

42. Slade EM, Roslin T, Santalahti M, Bell T. Disentangling the "brown world" faecal-detritus interaction web: dung beetle effects on soil microbial properties. Oikos. 2015;125:629-35.

43. Ponge J-F, Pérès G, Guernion M, Ruiz-Camacho N, Cortet J, Pernin C, et al. The impact of agricultural practices on soil biota: a regional study. Soil Biol Biochem. 2013;67:271-84.

44. Ibrahim TG, Fenton O, Richards KG, Fealy RM, Healy MG. Spatial and temporal variations of nutrient loads in overland flow and subsurface drainage from a marginal land site in south-east Ireland. Biol Environ. 2013;113B:259-71.

45. Schulte RPO, Diamond J, Finkele K, Holden NM, Brereton AJ. Predicting the soil moisture conditions of Irish grasslands. Irish J Agric Food Res. 2005:44:95-110.

46. Grossman RB, Reinsch TG. Bulk Density and Linear Extensibility. In: Dane JH, Topp GC, editors. SSSA book series, methods of soil analysis: part 4 physical methods. Madison: Soil Science Society of America; 2002. p. 201-28.

47. Gee GW, Or D. Particle-Size Analysis. In: Dane, Topp GC, editors. SSSA book series, methods of soil analysis: part 4 physical methods. Madison: Soil Science Society of America; 2002. p. 255-93.
48. Creamer RE, Simó I, Reidy B, Carvalho J, Fealy RM, Hallett S, et al. Irish Soil Information System Synthesis Report. Johnstown Castle, Co.: Wexford; 2014.

49. IUSS Working Group WRB. World reference base for soil resources 2006. World Soil Resour. Reports No. 103. Rome: FAO; 2012

50. Schmidt O, Curry JP. Population dynamics of earthworms (Lumbricidae) and their role in nitrogen turnover in wheat and wheat-clover cropping systems. Pedobiologia. 2001;187:174-87.

51. Lagerlöf J, Goffre B, Vincent C. The importance of field boundaries for earthworms (Lumbricidae) in the Swedish agricultural landscape. Agric Ecosyst Environ. 2002;89:91-103.

52. Gutiérrez-López M, Moreno G, Trigo D, Juárez E, Jesús JB, Díaz Cosín DJ. The efficiency of earthworm extraction methods is determined by species and soil properties in the Mediterranean communities of CentralWestern Spain. Eur J Soil Biol. 2016;73:59-68.

53. Zaborski ER. Allyl isothiocyanate: an alternative chemical expellant for sampling earthworms. Appl Soil Ecol. 2003;22:87-95.

54. Sims RW, Gerard BM. Earthworms. revised. Shrewsbury, Shropshire, UK: Field Studies Council; 1999.

55. R Core Team. R: A Language and Environment for Statistical Computing. R Found. Stat. Comput. Vienna, Austria; 2016.

56. Lenth R. Least-squares means: the R Package Ismeans. J Stat Software. 2016;69:1-33.

57. Legendre P, Legendre L. Numerical ecology. 2nd ed. Dev Environ Model. Amsterdam: Elsevier B.V.; 1998.
Ready to submit your research? Choose BMC and benefit from:

- fast, convenient online submission

- thorough peer review by experienced researchers in your field

- rapid publication on acceptance

- support for research data, including large and complex data types

- gold Open Access which fosters wider collaboration and increased citations

- maximum visibility for your research: over $100 \mathrm{M}$ website views per year

At BMC, research is always in progress.

Learn more biomedcentral.com/submissions 